\title{
The Influence of Competency, Usage of It and Career Expectation on Internal Auditor's Effectiveness in Ggovernment Linked Companies (GLCs)
}

\author{
Sharifah Nazatul Faiza Syed Mustapha Nazri ${ }^{1}$, Mohd Ikram Abdul Rasib ${ }^{2} \&$ Salwa Zolkifli ${ }^{1}$ \\ ${ }^{1}$ Faculty of Accountancy, Universiti Teknologi MARA, Malaysia \\ ${ }^{2}$ Bank Negara, Malaysia \\ Correspondence: Sharifah Nazatul Faiza Syed Mustapha Nazri, Faculty of Accountancy, Universiti Teknologi \\ MARA, Malaysia.
}

Received: April 20, 2019

Accepted: May 7, 2019

Online Published: May 19, 2019

doi:10.5430/ijfr.v10n3p337

URL: https://doi.org/10.5430/ijfr.v10n3p337

\begin{abstract}
National Audit Department (NAD) had repetitively recommended Federal Ministries/ Departments and Government-Linked Companies (GLCs) through its Auditor-General's Report on the need to have an effective internal audit function to identify and mitigate weaknesses in their activities. Therefore, the purpose of this study is to examine factors that influence the effectiveness of the internal auditors especially for those that work in GLCs in Malaysia. It is to determine the internal auditors' perception toward the effectiveness of internal audit activities, influenced by the individual factors related to the internal auditors themselves. This study also aims to determine the relationship between factors that contribute to the effectiveness. 300 questionnaires were distributed to internal auditors that work in GLCs in Malaysia using convenience sampling method, of which, 124 internal auditors had responded. Several statistical techniques such as the descriptive statistic, correlation and regression analysis were used to analyse the data from the survey. The result of the study showed that there were significant relationships among the factors analysed in this study which are the internal auditors' competency, usage of information technology (IT) and career expectation. Hence, the effectiveness of internal audit will depend strongly to the attributes of the factors analysed in this study. This study will help organisations especially GLCs in understanding the factors that influence the internal auditors' effectiveness and taking necessary action to improve their internal audit function. Consequently, the internal audit function could perform better in reporting findings and giving significant recommendations that give impact to the organisations.
\end{abstract}

Keywords: internal audit, effectiveness, competency, information technology, career expectation

\section{Introduction}

Internal audit is intended to be an independent, objective assurance and consulting activity designed to add value and improve an organisation's operations (https://global.theiia.org). It is an important part of the internal control framework that help the organisation to achieve its objectives by evaluating and improving the effectiveness of risk management, internal controls and governance processes of the organisation.In regard to the public sector auditing, Malaysia had developed National Audit Department (NAD) with the purpose to assist the public sector in ensuring integrity and good governance in managing public fund. Similarly, the National Audit Office (NAO) was established in UK to scrutinises public spending for Parliament to help the government in its drive to improve public services, nationally and locally.Likewise, the Australian National Audit Office (ANAO) was setup in Australia to improve public sector performance and support accountability and transparency in the Australian Government sector through independent reporting to the Parliament, the Executive and the public.

Internal audit function helped to improve the performance of the public sector and government organisations, especially in increasing the number of savings. For instance, the Auditor-General of Malaysia in 2016 stated that government agencies had recovered an estimated RM2 billion in follow-up actions from the issues raised in the audit reports (The Star Online, 2016). Similarly, NAO's recommendations and reports helped UK government to improve public services which led to audited savings of $£ 1.21$ billion in 2015(https://www.nao.org.uk). The improvement was also noted in Australia where the government had realised \$3.9 billion in savings since 2012 across all its fraud and 
compliance activities as audited by ANAO (Minister for Human Services, 2017).

However, there are a lot of weaknesses in relation to the financial management and activities conducted by the federal ministries/departments, Government-Linked Companies (GLCs) and Federal Government-linked agencies. For instance, a total of 1,695 warnings were issued following the Auditor-General's Report 2015 of which 85 (5\%) were punitive warnings due to matters related to embezzlement, abuse of power, misconduct, or negligence in the execution of duties as compared to 49 punitive warnings in the year 2014 (The Sun Daily, 2016). The number increased to 103 in the latest Auditor-General's Report 2016 out of 895 audit warnings reported during the first series of the report (The Sun Daily, 2017d).

In response to this issue, the current Auditor-General mentioned the report still contained findings of negligence, indiscipline, misappropriation, power abuse, corruption, and misconduct among the civil servants (The Sun Daily, 2017b). The Auditor-General also stated there are ministries, government agencies, and departments that failed to fully comply with the stipulated financial regulations in managingthe accounting records. In addition, the weaknesses were due to negligence in compliance with the stipulated financial rules or procedures, insufficient manpower, lack of training in financial management, inadequate supervision, and close monitoring (The Sun Daily, 2017c). This is happening due to lack of good internal control mechanism in respective organisations, which calls for research on effective internal control system.

Many research have been conducted to study the internal auditors in public sector environment in Malaysia (Ali, Gloeck, Ali, Ahmi, and Sahdan, 2007;Ahmad et al., 2009;Ahmad, Othman, and Othman, 2010;Rasit, Saidin, Sahdan, Rahim,Gloeck and Ali, 2013;Shamsuddin, Manjiegar and Kirupanangtan, 2014;Baharud-din, Shokiyah and Ibrahim, 2014; Chidoko and Mashavira, 2014; Salvioni and Gennari, 2014; Razek, 2014; Othman, Aris, Mardziyah, Zainan and Amin, 2015;Yusof, Haron, and Ismail, 2016; Eshiet, 2017; Mejdoub and Arab, 2017; Oitsile., Galebotswe and Sekwati, 2018; Chang'ach, 2018). However, the focus of those studies is more towards internal auditors in the state and federal government who are actually the employees of NAD and are placed there for a period of time before being transferred to another department (Romli and Ismail, 2014; Ekpung, 2014; Sarwar and Mubarik, 2014 ; Ali, et.al. 2016; Okon and Monday, 2017; Kimengsi and Gwan, 2017; Bollazzi and Risalvato, 2018; Omodero and Ogbonnaya, 2018). Consequently, there are limited studies that focusedon or with samples obtained from internal auditors of organisations related to the government, such as the federal government's statutory bodies, agencies under government, government-linked companies (GLCs), and government-linked investment companies (GLICs), which were hired directly by the organisations. This call for a study to identify the factors that could influence the internal auditors' effectiveness in the public sector, especially the internal auditors in GLCs.

Therefore, the purpose of this study is to examine factors that influence the effectiveness of the internal auditors especially for those that work in GLCs in Malaysia, focusing on the auditor's competency, usage of the information technology (IT) and career expectation. It is to determine the internal auditors' perception toward the effectiveness of internal audit activities, influenced by the individual factors related to the internal auditors themselves. This study also aims to determine the relationship between factors that contribute to the effectiveness.

\section{Literature Review}

\subsection{Expectancy Theory}

In researching the factors that influence the internal auditors' activities, this study uses expectancy theory developed by Vroom (1964) to support the selection of variables. Expectancy theory is used to generate predictions of how hard the employees work on their jobs and how effective is their performance. It states that work motivation is high when employees believe that high levels of effort lead to high performance and high performance leads to the attainment of desired outcomes (Jones \& George, 2015). Thus, three kinds of information must be obtained from the employees: (a) a list of outcomes that they expect to obtain as a result of "working hard" on a job (Expectancy); (b) an estimate of their level of certainty that the outcomes will, in fact, be obtained as a result of working hard (Instrumentality); and (c) an estimate of the degree to which they like or dislike the outcomes (Valence) (Hackman \& Porter, 1968). Hence, the theory could be summarised as per Figure 1. 


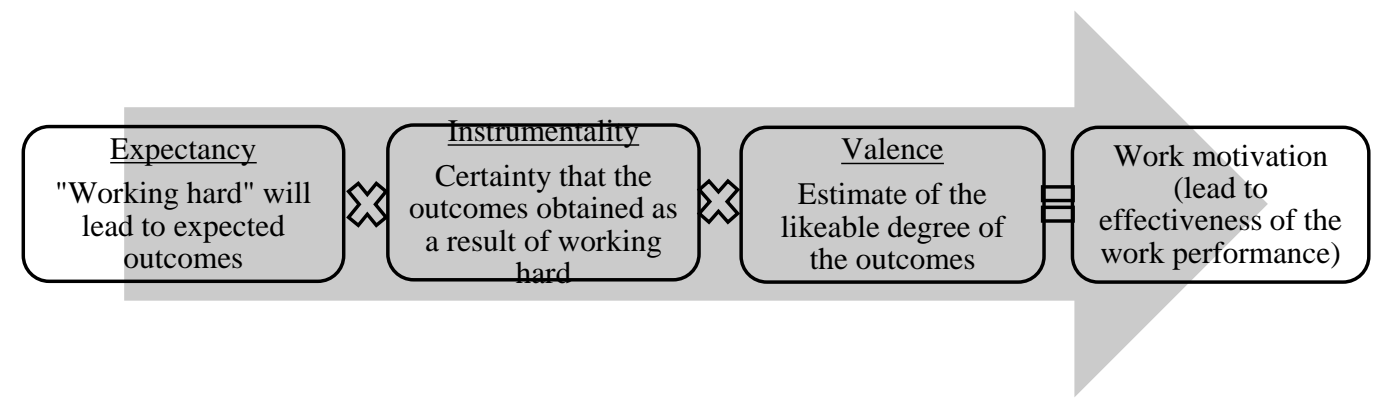

Figure 1. Expectancy theory (adaptedbased on explanation by Jones \& George, 2015)

According to the theory, working hard or giving effort will lead to expected outcomes. Burns, Roberts, Posey, Bennett, and Courtney (2015) further explained theexpectancy theory where the perception of effort will lead to the performance of a behaviour linked directly to behavioural motivation. Hence, people who are motivated will put an effort that leads to the intended performance. The study also indicated that education, training, and awareness worked through unique expectancy dimensions in motivating distinct behaviours. Therefore, it could be said that by being motivated to become competent, an internal auditor will work hard and gives a better effort, hence, they become more effective in their activities.

Figure 2 shows the theoretical framework of thisstudy. The dependent variable in this study is the effectiveness of the internal auditors' activities. The main objective of this study is to examine the factors influencingthe internal auditors' effectiveness in performing their activities, thus, the independent variables are the internal auditors' competency, usage of IT and career expectation.

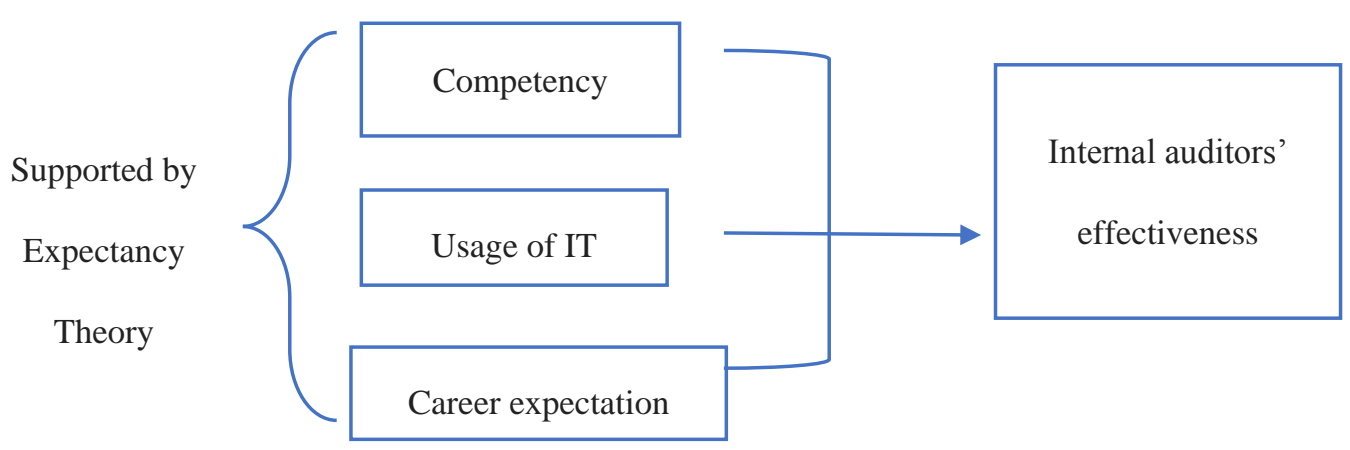

Figure 2. Theoretical Framework of This Study

\subsection{Overview of Internal Auditing in Malaysia}

Internal auditing could be defined as an independent, objective assurance, and consulting activity designed to add value and improve an organisation's operations. It helps an organisation to accomplish its objectives by bringing a systematic, disciplined approach to evaluate and improve the effectiveness of risk management, control, and governance processes (https://global.theiia.org). The definition was developed by the Institute of Internal Auditors (IIA), which could be said as the starting point of the modern internal auditing (Ali et al., 2009).

The historical development of internal auditing in the Malaysian public sector is well documented by scholars, such asAli et al. (2007), Ali et al. (2009), Ahmad et al. (2009) andYusof et al. (2016), as well as the circulars issued by Treasury Malaysia. The development started with the establishment of an internal audit department by the Ministry of Defense in 1970, although the scope is limited only to financial audit (Yusof et al. 2016). The Malaysian government released the Treasury Circular No. 2 in 1979, entitled Implementation of Internal Auditing in Federal Government Agencies, which required all ministries and departments in the Federal Government to establish their internal audit unit or department (Ali et al. 2009). The circular detailed the roles and responsibilities of an internal 
audit function, types of audit, and the scope of the audit to be conducted in the ministries and government departments.

The need to have an internal audit function in the organisations in Malaysia had been highlighted in the Malaysian Code of Corporate Governance (MCCG) since 2000. The MCCG 2000 had recommended that the Board Audit Committee should establish an internal audit function within the organisations (Finance Committee on Corporate Governance, 2000). Subsequently, the revised version of the MCCG in 2007 stated that the internal audit function are required in all public listed companies and the reporting line for the internal auditors are clarified (Securities Commission, 2007). The MCCG was again revised in 2012 and recommended for the board of the organisations to establish the internal audit function which reports directly to the Audit Committee (Securities Commission Malaysia, 2012). Finally, a new MCCG was introduced in 2017 and stated that the Audit Committee should ensure that the internal audit function is effective and able to function independently within the organisations (Securities Commission Malaysia, 2017).

\subsection{Internal Audit's Effectiveness}

The Institute of Internal Auditors stated that the internal auditing plays a critical role in the governance and operation of an organisation. It further added that when effectively implemented, operated, and managed, the internal audit function is an important element in helping an organisation to achieve its objectives. Furthermore, organisations that use internal auditing effectively will be able to identify business risks and process and system inefficiencies as well as take appropriate corrective action and ultimately support continuous improvement (https://global.theiia.org).

Many scholars explicated the importance of an internal audit function to an organisation. Cohen and Sayag(2010) mentioned the aim of an internal auditing is to improve organisational efficiency and effectiveness through constructive criticism. Soh and Martinov-Bennie(2011) indicated the internal audit function provides an internal assurance of the corporate governance processes including the internal control and risk management of the organisation. However, to achieve the intended potential and significant benefits for the organisation, the internal audit function must first show a superior level of performance and effectiveness (Feizizadeh, 2012). The effectiveness of the internal audit will then contribute to the effectiveness of the organisations as a whole as evidenced by many findings from the previous research that linked the internal auditor's effectiveness to the organisation's effective management and internal control (Baharud-din et al., 2014).

Several studies have been conducted in regard to the effectiveness of the internal audit function either from an organisational or individual perspective. In explaining the definition of internal audit effectiveness, the Institute of Internal Auditors used the general description, which is the degree (including quality) to which the established objectives are achieved (https://global.theiia.org). In addition, scholars also attempted to further define the internal audit effectiveness. For instance, Mihret and Yismaw (2007) stated that internal audit effectiveness means the extent to which an internal audit office meets its purposes, whilst Mizrahi and Ness-Weisman (2007) simply described auditing effectiveness as the number and scope of deficiencies corrected following the auditing process. Ussahawanitchakit and Intakhan (2011)defined audit effectiveness as an outcome of the auditors' professional practices, duties, activities, and responsibilities by committing to the audit standards, objectives, goals, and policies. Meanwhile, Badara and Saidin (2013) designated internal audit effectiveness as the ability of the internal auditor to achieve the established objective of an organisation.

Feizizadeh (2012) asserted thatthe internal audit function needs to demonstrate its effectiveness using a performance measurement system tied to the expectations of its key stakeholders such as balanced scorecards. The internal audit function can meet the expectations of the board, senior management, and operating management by identifying the expectations and regularly tracking its performance against the expectations of the key stakeholders.

There are few factors which influence the effectiveness of internal audit of an organisation. However, this study focuses on three main factors under auditor individual attributes, which are internal auditor's competency, usage of IT and career expectation.

\subsection{Internal Auditors' Competency}

Hudiwinarsih (2010) stated that there is a significant effect of experience and competence towards the auditor's professional attitude. Competency also has significant effect towards audit quality as discovered by Furiady and Kurnia (2015). Sulistyowati and Supriyati (2015) also acknowledged that competency and professionalism had significant effect on the fraud detection. Another study by Kolibácová (2014) found that when the competency rate of an employee increases, the performance rate of the employee also increases.

Study by Iskandar et al. (2014) found that the higher the level of competency of internal auditors, the better the 
financial management performance of the organisation. This was agreed by Zaim et al. (2013) which concluded that there is a positive relationship between competency and individual and organisational performance. Competency also contributes to perceived effectiveness of the internal audit function in the public sector as discovered by Alzeban and Gwilliam (2014).

Auditor who has competencies in terms of adequate knowledge, experience, education, and training could also conduct audits objectively and accurately (Sulistyowati \& Supriyati, 2015). Auditing experience and professionalisation also positively influence the professional awareness of the auditors. In addition, acquired knowledge and skillset can effectively improve auditors' professional judgment and subsequently may significantly impact any performance involved (Su et al., 2016).

Hence, this study develops the following hypothesis:

H1: There is a relationship between internal auditors' competency and the effectiveness of the internal auditors' activities.

\subsection{Usage of IT}

Chaveerug (2011) stated that knowledge on IT such as accounting information system has positive relationships with audit effectiveness. IT usage by the internal auditors and the level of top management support towards the usage are important to increase the internal audit effectiveness (Alkebsi et al., 2014). On the other hand, it will be difficult for the auditors to not rely on IT tools when auditing as the accounting systems are becoming more complex and sophisticated over the years due to the rapid development of IT (Ahmi et al., 2016).

Auditors with sufficient IT skills will significantly improve effectiveness of auditing while reducing the dependence on IT staff (Sun, 2012). This was supported by Mahzan \& Lymer (2014) where the study found that the main motivation to use audit software is that it would greatly enhance the auditors' job efficiency and are able to automate parts of the audit process to improve overall performance. In this regard, audit methodologies \& work procedures could be improved further by using IT if the auditors are willing to learn to use it ( $\mathrm{Su}$ et al., 2016).

Organisations generally acknowledge that the benefits of audit technology implementation outweigh the implementation costs (Rosli et al., 2016). This was agreed by Mustapha and Lai (2017) as the study found that the reason the auditors did not use the information technology software was not because of itshigh investments and costs. Nowadays, the costs were already budgeted and provided by a lot of audit firms to equip their firms with latest technologies to ensure that they are able to match the expectation of their clients.

Thus, this study develops the following hypothesis:

$\mathrm{H} 2$ : There is a relationship between the usage of IT in auditing and the effectiveness of internal auditors' activities

\subsection{Career Expectation}

Study by Gong and Chang (2008) revealed that career advancement was positively related to the organisation performance. This was supported by Crawshaw et al. (2012) where the study found that high performance is generated through the provision of valued and marketable career development opportunities offered by the organisation. On the other hand, the organisation might lose the skilled and competent employees if they fail to experience internal work motivation and satisfaction due to a lack of expectation and may pursue changes in their job (Fried et al., 2007).

Abele and Spurk (2009) found in their study that the higher the respondents set their self-efficacy and career advancement goals at the beginning of their career, the more they earned and the higher was their status in the later years. This might be due to when they are satisfied with their job and career, they tend to have a greater sense of responsibility and be more passionate in their work hence, enable them to perform better and gain higher status in their career (Kong et al., 2015).

Güngör (2011) found that motivation such as extrinsic (financial rewards) and intrinsic (non-financial rewards) have an impact on the employee performance. This was agreed by Kraimer et al. (2011) as the study discovered that employees' perception of attractive career opportunity were necessary for the employees to increase their performance and decrease the likelihood of turnover. Another study on the subject of university lecturers by Manyasi (2013) similarly concluded that university incentives for career development positively influenced the lecturers' performance.

Therefore, this study develops the following hypothesis:

H3: There is a relationship between career expectation and the effectiveness of the internal auditors' activities 


\section{Research Methodology}

This study used a quantitative method and a correlational design to examine the relationship between the variables. Information will be obtained through the correlational study and statistical analysis of the variables whichprovide a logical method for this study to answer the research questions and provide contribution to the industry and the academician.The research questions of this study addressed the relationship between the internal auditors' competency level, the usage of IT, career expectation, and the effectiveness of the internal auditors' activities in their organisations. This study employed a nonprobability sampling using a convenience sampling technique where the samples are the internal auditors that work in several GLCs located in Kuala Lumpur, Malaysia. Ormrod and Leedy (2005) mentioned that convenience sampling technique is used due to the limitations of time or resources of the researcher. However, Uprichard (2013) assured that nonprobability sampling procedures had been used by researchers to extend the knowledge of the sample population.

\subsection{Survey Instrument}

The main source for the survey instruments was from a review of the existing literature and questionnaires used by other researchers, an approach recommended for studies of this nature (Bell \& Bryman, 2007). To examine the research questions, the survey instruments were derived from those used in four prior studies: Baharud-din et al. (2014), Ahmi et al. (2016), Güngör (2011), and Alzeban and Gwilliam (2014). The independent variable was measured based on a five-point Likert scale: $1=$ strongly disagree, $2=$ disagree, $3=$ neither agree nor disagree, $4=$ agree, $5=$ strongly agree. Due to the quantitative purpose of this research, this studyslightly rephrased the questionnaires used as and when needed to make them more contextually relevant to the present study.

Six demographic questions believed to be suitable for this study were included in addition to the survey instruments mentioned above. The demographic questions were selected based on the review of the existing literature. For example, question about the age of the respondents was asked as it showed relevance value in some studies whilstquestion about the marital status was not asked since it showed no significance value to the studies. Therefore, the survey contains 29 questions in total.

\subsection{Data Collection Technique}

The survey used in this study was distributed by both paper-based and online survey via the Google form. A total of 300 questionnaires which consist of 200 paper-based and 100 Google form links were send to the internal audit department of several GLCs located in Kuala Lumpur, Malaysia to be distributed to the internal auditors in the department. This study did not include the participants' names or their organisations' names to remain anonymous. The participants were not given any financial incentives to encourage voluntaryparticipationin this study.

The survey instrument was a vehicle for collecting data for this study. Once the data were collected, the responses were entered intoIBM Statistical Package for the Social Sciences 22 (SPSS) for analysis. Multiple linear regression analysis was conducted to answer the research questions requires the testing ofthe relationship between the independent variables and dependent variable, as explained by Cohen et al. (2013).

\section{Data Analysis and Discussion of Findings}

\subsection{Profile of Respondents}

A demographic profile of the participating internal auditors is presented in Table 1. The table includes respondents' information on gender, age, academic qualification, education background, position level, years of services. This study involves a total of 124 internal auditors with 68 males and 56 females. The youngest respondent is 23 -years-old whilst the oldest respondent is 58-years-old. The average age of the respondents for this study is 35.75 years old. Four age groups were categorised and each group extend over 10 years. The youngest age group was between 21 and 30 whilst the oldest age group was between 51 and 60, which is the standard retirement age for Malaysian. Approximately, 50\% of the respondents were aged between 31 and 40, followed by the age group of 21 to 30 that made up $28.2 \%$ and the age group of 41 to 50 was $16.1 \%$ of the total respondents. There were very few respondents at the age of 51 to 60 , which is $5.6 \%$ of the total respondents. The highest education qualification for most of the respondents were Bachelor's Degree (80.6\%) followed by Master's Degree (17.7\%). There is one respondent each for the Diploma and Doctorate level, which represent $0.8 \%$ of the total respondents.

As for respondents' education background, majority of the respondents are from Accountancy background (71.8\%), followed by Finance and IT background (both represents 7.3\%) and other background (13.7\%).Table 4 also displays the frequency of the respondents who belong to a professional body membership. Approximately $32.3 \%$ of the respondents belong to a professional accounting body, such as ACCA, MIA, and CPA Australia whilst $30.6 \%$ of the 
respondents are members of a professional internal audit body that is IIA. Meanwhile, $6.5 \%$ of the respondents are members of a professional IT-related body such as ISACA and another $4.0 \%$ of the respondents belong to professional bodies from other related fields such as ACFE. Table 4.6 shows the number of respondents who are members of professional bodies (73.4\%), exceeded the number of respondents who are not part of one (26.6\%). As for the working experience of the respondents, the shortest number of experience of the respondents is 1 year whilst the longest number of experience of the respondents is 32 years. The average number of years of working experience of the respondents is 9.25 years. About $38.7 \%$ of the respondents have between six and 10 years of working experience while $31.5 \%$ have five years or less of working experience. Category 11 to 15 years consists of $14.5 \%$ of the respondents whilst $10.5 \%$ and $4.8 \%$ of the respondents are from category 16 to 20 years and more than 20 years, respectively.

The questionnaire also covers respondents' position. About $46.8 \%$ of the respondents are Senior Executive-level auditors whilst $25.8 \%$ are Executive-level auditors. Manager-level auditors made up 25.8\% of the respondents whilst only $1.6 \%$ of the respondents are the Head of Internal Audit Department in their respective organisations.According to the descriptive analysis above, the respondents are well educated as the majority (99.2\%) of them have a bachelor degree and above, which mean they would not have difficulty in understanding the questionnaire. About $71.8 \%$ of the respondents are from Accountancy background which indicates the organisations might prefer internal auditors that are capable to comprehend their operations through the bookkeeping and financial statements of the organisations. The majority of the respondents $(68.5 \%)$ also have at least six years of working experience in the internal auditing, which means they would not face difficulty in understanding the questions related to their perception of the activities as internal auditors.The majority of the respondents (73.4\%) also have professional qualifications, which means they have the capability to be effective as it is difficult for an organisation to become effective without professionally qualified staff (Cohen \&Sayag, 2010).

Table 1. Demographic profile of respondents

\begin{tabular}{lll}
\hline Profile & Frequency & Percentage, \% \\
\hline Gender: & 68 & \\
Male & 56 & 54.8 \\
Female & $\mathbf{1 2 4}$ & 45.2 \\
Total & & $\mathbf{1 0 0}$ \\
\hline Age & 35 & \\
$21-30$ & 62 & 28.2 \\
$31-40$ & 20 & 50.0 \\
$41-50$ & 7 & 16.1 \\
$51-60$ & $\mathbf{1 2 4}$ & 5.6 \\
Total & & $\mathbf{1 0 0}$ \\
\hline Academic Qualification: & 1 & \\
Diploma & 100 & 0.8 \\
Bachelor Degree & 22 & 80.6 \\
Master Degree & 1 & 17.7 \\
Doctorate & $\mathbf{1 2 4}$ & 0.8 \\
Total & & $\mathbf{1 0 0}$ \\
\hline Education Background & 89 & \\
Accountancy & 9 & 71.8 \\
Finance & 9 & 7.3 \\
IT & 17 & 7.3 \\
Other & $\mathbf{1 2 4}$ & 13.7 \\
Total & & $\mathbf{1 0 0}$ \\
\hline Professional Bodies & & \\
& &
\end{tabular}




\begin{tabular}{lll}
\hline Internal Audit & 38 & 30.6 \\
Accountancy & 40 & 32.3 \\
IT & 8 & 6.5 \\
Other & 5 & 4.0 \\
None & 33 & 26.6 \\
Total & $\mathbf{1 2 4}$ & $\mathbf{1 0 0}$ \\
\hline Working Experience: & & \\
5 years and less & 39 & 31.5 \\
6 to 10 years & 48 & 38.7 \\
11 to 15 years & 18 & 14.5 \\
16 to 20 years & 13 & 10.5 \\
More than 20 years & 6 & 4.8 \\
Total & $\mathbf{1 2 4}$ & $\mathbf{1 0 0}$ \\
\hline Position Level: & & \\
Executive & 32 & 25.8 \\
Senior Executive & 58 & 46.8 \\
Manager/Supervisor & 32 & 25.8 \\
Head of Department & 2 & 1.6 \\
Total & $\mathbf{1 2 4}$ & $\mathbf{1 0 0}$ \\
\hline
\end{tabular}

\subsection{Descriptive Statistics}

Table 2 shows the descriptive statistics of the variables based on the result of the questionnaire. According to Section B: Internal Auditors' Competency, the mean response of the questions is 4.18, which implies that on average, the respondents agreed to the statements on the competency of the internal auditors. The average standard deviation (SD) of the responses is 0.431 which is lower than 1.00. This indicates that the respondents' perceptions were close or similar to one another. As for Section C: Usage of IT, the mean response of the questions is 3.28 whichimplies thatthe respondents usually used IT in their working activities. The average standard deviations (SD) of the responsesis 0.868 which is lower but near to 1.00. It indicates that the respondents' perception wasquite far or differed from each other.

Furthermore, Table 2 states the descriptive statistics of Section D: Career Expectation by the internal auditors. The mean response of thequestionsis 4.20 , whichimplies that the respondents agreed on the statements regarding career expectation. The average standard deviations (SD) oftheresponsesis 0.486 which is lower than 1.00 . It indicates that the respondents' perception was close or similar to one another. Lastly, the descriptive statistics of Section E: Internal Auditors' Effectiveness shows mean response of 4.08. This implies therespondents' agreement on the effectiveness of the internal auditors in their activities. The average standard deviations (SD) of theresponsesis 0.394 which is lower than 1.00. It indicates that the respondents' perceptions were close or similar to one another.

Table 2. Descriptive statistics of the variables based on the questionnaire

\begin{tabular}{lll}
\hline Variable & Mean & Std. Deviation \\
\hline $\begin{array}{l}\text { Dependent Variable: } \\
\text { Internal Auditors' Effectiveness }\end{array}$ & 4.08 & 0.394 \\
\hline Independent Variable: & & \\
Competency & 4.18 & 0.431 \\
Usage of IT & 3.28 & 0.868 \\
Career Expectation & 4.20 & 0.486 \\
\hline $\mathbf{N}=\mathbf{1 2 4}$ & & \\
\hline
\end{tabular}




\subsection{Reliability Analysis}

Reliability analysis has been employed in prior studies relating to internal audit using a Likert-scale questionnaire such asAbdullaziz Alzeban and Gwilliam (2012) and Baharud-din et al. (2014). To measure such a reliability analysis, Cronbach's alpha $(\alpha)$ is the most common measure of reliability scale. According to Field (2009), a reliability analysis value greater than .700 is highly acceptable. A reliability analysis was run using all 124 respondent's questionnaires. The reliability analysis value for Cronbach's alpha $(\alpha)$ of this study is .909 for all variables. Therefore, the responses generated from all variables of this study are reliable and highly acceptable for data analysis.

Table 3 shows the Cronbach's alpha individual result of all the variables. The Cronbach's alpha value for Internal Auditors' Effectiveness is .890 , which is consistent with the value from the previous studies that examined the effectiveness of an internal audit, such as .731 by Baharud-din, Shokiyah and Ibrahim (2014) and .880 by Alzeban and Gwilliam (2014). Next, the Cronbach's alpha value for Internal Auditors' Competency is .704. The result is comparable with the value from other studies that examined competencies such as .780 by Alzeban and Gwilliam (2014) and .722 by Baharud-din et al. (2014).

The Cronbach's alpha value for the Usage of IT is .941. The value is comparable with the value from other related studies that examined information system such as .910 by Chaveerug (2011) and above .700 by Tippins and Sohi (2003). Finally, the Cronbach's alpha value for Career Expectation is .886. The value is consistent with the value from the previous studies on career expectation such as .770 by Abele and Spurk (2009) and 0.918 by Cohen and Sayag (2010). All the Cronbach's alpha values for the variables indicated the questions adopted for the questionnaire are reliable and highly acceptable as the Cronbach's alpha is more than .700 (Field, 2009).

Table 3. Reliability and validity statistics for variable

\begin{tabular}{lll}
\hline Variable & Cronbach's Alpha & N of Items \\
\hline Internal Auditors' Effectiveness (DV) & .890 & 15 \\
\hline Internal Auditors' Competency & .704 & 6 \\
\hline Usage of IT & .941 & 10 \\
\hline Career Expectation & .886 & 10 \\
\hline Total Reliability & .909 & 41 \\
\hline
\end{tabular}

\subsection{Multiple Regression Analysis}

Table 4 displays the model summary of multiple regression analysis. The R square value of .293 shows that $29.3 \%$ of the variation in the internal auditors' effectiveness is explained by the variation of the independent variables, namely, internal auditors' competency, the usage of IT, and career expectation,taking into account the sample size and number of independent variables. The remaining $70.7 \%$ of the internal auditors' effectiveness is defined by other variables.

Table 4 also displays the coefficients (both, standardised, and unstandardised) of the multiple regression analysis. The beta value represents the strength of the relationship between internal auditors' effectiveness and the internal auditors' competency, the usage of IT, and career expectation. It shows the effect of independent variables on the dependent variable (Field, 2009). The beta value for the independent variables in the table shows a positive value, which means the independent variables (internal auditors' competency, usage of IT, and career expectation)have a positive effect on the dependent variable (internal auditors' effectiveness). Any increase in the independent variables leads to an increase in the dependent variable, which is consistent with the prior research, such asAhmad et al. (2010), Cohen and Sayag (2010), Baharud-din et al. (2014) and Alzeban and Gwilliam (2014).

Table 4 also shows the tolerance and variance inflation factor (VIF) of the collinearity statistics for the individual independent variables. A variable shows no multicollinearity issues when it has a VIF of less than 10 (Pallant, 2013). Therefore, there are no multicollinearity issues as all the individual VIF of all the independent variables are way below than 10 .

The independent variable with the level of significance (sig. or p-value) value less than $5 \%$ can make a significant contribution to the predicted value of the dependent variable. Whereas, a variable beyond this level of significance cannot make a significant contribution to the predicted value of the dependent variable (Brooks, 2014). Based on 
Table 4.18, the Internal Auditors' Competency has a $p$-value of .004 , which is less than .05 , hence indicating a significant relationship between Internal Auditors' Competency and Internal Auditors' Effectiveness. The beta or 'B' value of the standardised coefficients has a value of .240 , which indicates that for every unit increase in Internal Auditors' Competency will result in $24 \%$ unit increase in the Internal Auditors' Effectiveness. Hence, there is a direct significant relationship between Internal Auditors' Competency and Internal Auditors' Effectiveness. The result is consistent with the previous studies, such as Ahmad et al. (2010), Alzeban and Gwilliam (2014) and Baharud-din et al. (2014).

From the multiple regression analysis, the Usage of IT has a $p$-value of .005, which is less than .05 , hence indicating a significant relationship between the Usage of IT andInternal Auditors' Effectiveness. The beta or ' $\mathrm{B}$ ' value of the standardised coefficients has a value of .222, which indicates that for every unit increase in the Usage of IT will result in 22.2\% unit increase in Internal Auditors' Effectiveness. Therefore, there is a direct significant relationship between the Usage of IT and Internal Auditors' Effectiveness. The result is supported by the previous studies, such as Chaveerug (2011) andAlkebsi et al. (2014).

Based on the result of the multiple regression analysis, Career Expectation has a $p$-value less than .001 hence, indicating a significant relationship between Career Expectation and Internal Auditors' Effectiveness. The beta or 'B" value of the standardised coefficients has a value of .334, which indicates that for every unit increase in Career Expectation will result in 33.4\% unit increase in Internal Auditors' Effectiveness. Hence, there is a direct significant relationship between Career Expectation and Internal Auditors' Effectiveness. The finding is supported by prior studies, such as Cohen and Sayag (2010) andKraimer et al. (2011).

Table 4. Multiple regression results

\begin{tabular}{llll}
\hline Variable & Coefficient $\boldsymbol{B}$ & $\boldsymbol{t}$-value & $\boldsymbol{p}$-value \\
\hline Constant & 25.492 & 4.863 & .000 \\
\hline Competency & 0.548 & 2.908 & .004 \\
\hline Usage of IT & 0.151 & 2.871 & .005 \\
\hline Career & 0.406 & 4.082 & .000 \\
\hline $\mathrm{R}^{2}$ & .293 & & \\
\hline Adjusted $\mathrm{R}^{2}$ & .275 & & \\
\hline$F$-value & 16.576 & & \\
\hline$p$-value & $.000^{*}$ & & \\
\hline $\mathrm{N}$ & 124 & & \\
\hline
\end{tabular}

\section{Discussion on Results and Findings}

This section presents the results of the data analysis. The hypotheses testing are used to test a significant influence of the independent variables on the dependent variable (Field, 2009). In this study, the hypotheses testing areused to test the significant influence of the internal auditors' competency, the usage of IT, and career expectation on the internal auditors' effectiveness, which was measured in the value added to a business, enhanced department performance, and enhanced organisational performance. According to Table 4.18, the $p$-value for internal auditors' competency, the usage of IT, and career expectation are statistically significant at $(p<0.05)$, which shows a strong support for Hypothesis 1, Hypothesis 2, and Hypothesis 3. The findings are summarised in Table 5.

Table 5. Summary of the main findings

\begin{tabular}{l}
\hline H1: There is a significant relationship between internal auditor's competency and $\sqrt{ }$ \\
internal auditors' effectiveness. \\
H2: There is a significant relationship between the usage of IT and the internal $\sqrt{ }$ \\
auditors' effectiveness. \\
H3: There is a significant relationship between career expectation and internal $\sqrt{ }$ \\
auditors' effectiveness.
\end{tabular}


Internal audit plays an important role in helping the government-related organisations to achieve their objectives and mitigate weaknesses when the internal audit function is implemented, operated, and managed, effectively. The competency of the internal auditors plays a critical role in the internal auditors' effectiveness. It means that traits such as knowledge, qualification, skills, and experience of the internal auditors have a significant effect on the effectiveness of the internal auditors in an organisation. Evidently, one of the shortcomings of the internal auditors in the government sector that needsthe most urgent attention is related to the competency of the audit staff,that is, the staff are lacking in appropriate audit skills (Ali et al., 2009). Therefore, this study examined whether the internal auditors' competency has any relationship with the internal auditors' effectiveness. To conclude, internal auditors' competency is positively associated with the internal auditors' effectiveness in an organisation at a statistical significance level of $(p<0.05)$.

With the rapid development of IT and sophisticated systems that are commonly used in the organisations' daily operations, such as accounting, financing, economics, and investment, the internal auditors will face difficulties in auditing such systems effectively without using any IT-related tools. Ahmi et al. (2016) concluded that the level of IT adoption by the internal audit unit in Malaysian public sector is high although the usage is considerably low, specifically in auditing such as the use of CAATs. It is important for the internal auditors to equip themselves with the necessary knowledge and skills related to IT as well as to possess qualification from IT-related professional body if necessary. Thus, this study examined whether the usage of IT by the internal auditors has any relationship with the internal auditors' effectiveness. To conclude, the usage of IT is positively associated with the internal auditors' effectiveness in an organisation at a statistical significance level of $(p<0.05)$.

Although internal auditors need to independently review and assess the organisations' objectives and operations, they are still the employee of the organisations. The internal auditors have their expectations regarding their career when performing their works and this might affect the effectiveness of the work performed by the internal auditors. According to Güngör (2011), organisations are seeking to develop, motivate, and increase the performance of their employees throughvarious human resources applications such as the reward management system. Hence, this study examined whether the internal auditors' career expectation has any relationship with the internal auditors' effectiveness. To conclude, career expectation is positively associated with the internal auditors' effectiveness in an organisation at a statistical significance level of $(p<0.05)$.

Therefore, the internal auditors' competency, the usage of IT and career expectation have a strong and statistically significant effect on the internal auditors' effectiveness in enhancing the organisational performance.

\section{Conclusion}

Internal audit is intended to be an independent, objective assurance and consulting activity designed to add value and improve an organisation's operations (https://global.theiia.org). It is an important part of the internal control framework that help the organisation to achieve its objectives by evaluating and improving the effectiveness of risk management, internal controls and governance processes of the organisation.However, there are a lot of weaknesses in relation to the financial management and activities conducted by the federal ministries/departments, Government-Linked Companies (GLCs) and Federal Government-linked agencies. This call for a study to identify the factors that could influence the internal auditors' effectiveness in the public sector, especially the internal auditors in GLCs. Therefore, this study was conducted to examine factors that influence the effectiveness of the internal auditors especially for those that work in GLCs in Malaysia, focusing on the auditor's competency, usage of the information technology (IT) and career expectation. Findings show that internal auditors' competency, usage of IT and career expectation have a strong and statistically significant effect on the internal auditors' effectiveness in enhancing the organisational performance.

The study makes an incremental contribution to existing literature by providing insights on the factors that influence effectiveness of internal audit in public sector, focusing on the GLCs. It also discussed on the importance of proper assessment on the internal auditor's effectiveness in public sector. The study also contributes to the industry, by understanding the factors which influences the effectiveness of the internal audit in GLCs in Malaysia and recommends improvement actions which can be considered by the organisations to improve its current internal audit mechanism.

Since the sample size used in the study is relatively small, it cannot be generalised to a larger population of internal auditors in the public sector. This study also only considers on three independent variables, although there are many other independent variables which may influence the internal auditors' effectiveness not mentioned in this study. Therefore, this study encourages further research to extend the results of this study and improve the results by minimising the limitation of the study. Future research may be conducted on larger sample size to exploring the 
emerging issues that clouding the GLCs in Malaysia and the role of the internal auditors in the GLCs in combatting the problems that had been plaguing the GLCs.

\section{References}

Abele, A. E., \& Spurk, D. (2009). The longitudinal impact of self-efficacy and career goals on objective and subjective career success. Journal of Vocational Behavior, 74(1), 53-62. https://doi.org/10.1016/j.jvb.2008.10.005

Ahmad, H. N., Othman, R., \& Othman, R. (2010). Internal and External Factors Influencing Effectiveness of Internal Audit Department (IAD) in Malaysian Local Authorities. Australia \& New Zealand Academy of Management, 1-18.

Ahmad, N., Othman, R., Othman, R., \& Jusoff, K. (2009). The Effectiveness of Internal Audit in Malaysian Public Sector. Journal of Modern Accounting and Auditing, 5(9), 53-62.

Ahmi, A., Saidin, S. Z., Abdullah, A., Ahmad, A. C., \& Ismail, N. A. (2016). State of Information Technology Adoption by Internal Audit Department in Malaysian Public Sector. International Journal of Economics and Financial Issues, 6, 103-108. Retrieved from https://www.econjournals.com/index.php/ijefi/article/view/3589

Ali, A. M., Ahmi, A., Ali, A., Ghazali, M. Z., Gloeck, J. D., \& Lee, T. H. (2009). Internal audit in the federal organizations of Malaysia: is there light at the end of the long dark tunnel?. Southern African Journal of Accountability and Auditing Research, 9, 23-38.

Ali, A. M., Gloeck, J., Ali, A., Ahmi, A., \& Sahdan, M. (2007). Internal audit in the state and local governments of Malaysia. Southern African Journal of Accountability and Auditing Research, 7, 25-57. https://doi.org/10.1504/IJAF.2010.032088

Ali, K., Khan, Z., Khan, N., Alsubaie, A. H. I., Subhan, F., \& Kanadil, M. (2016). Performance Evaluation of UK Acquiring Companies in the Pre and Post-Acquisitions Periods. Asian Journal of Economics and Empirical Research, 3(2), 130-138.

Alkebsi, M., Aziz, K. A., Mohammed, Z. M., \& Dhaifallah, B. (2014). The Relationship Between Information Technology Usage, Top Management Suppport And Internal Audit Effectiveness. International Management Accounting Conference (pp. 321-336). Retrieved from http://aaajournals.org/doi/10.2308/jis.2009.23.1.79

Alzeban, A., \& Gwilliam, D. (2012). Perceptions of Managers and Internal Auditors as to Factors Affecting the Effectiveness of Internal Audit in the Public Sector Context. Academic Conference on Internal Audit and Corporate Governance, pp. 1-24. Retrieved from http://www.iacmaster.it/iacgconference2012/wp-content/uploads/2012/04/aziz-gwilliam.pdf

Alzeban, A., \& Gwilliam, D. (2014). Factors affecting the internal audit effectiveness: A survey of the Saudi public sector. Journal of International Accounting, Auditing and Taxation, 23(2), 74-86. https://doi.org/10.1016/j.intaccaudtax.2014.06.001

Badara, M., \& Saidin, S. (2013). Impact of the effective internal control system on the internal audit effectiveness at local government level. Journal of Social and Development Sciences, 4(1), 16-23. https://doi.org/10.5923/j.jija.20130202.05

Baharud-din, Z., Shokiyah, A., \& Ibrahim, M. S. (2014). Factors that Contribute to the Effectiveness of Internal Audit in Public Sector. International Proceedings of Economics Development and Research, 70(24), 126-132. https://doi.org/10.7763/IPEDR.

Bell, E., \& Bryman, A. (2007). The ethics of management research: An exploratory content analysis. British Journal of Management, 18(1), 63-77. https://doi.org/10.1111/j.1467-8551.2006.00487.x

Bollazzi, F., \& Risalvato, G. (2018). Corporate Responsibility and ROA: Evidence from the Italian Stock Exchange. Asian Economic and Financial Review, 8(4), 565-570.

Brooks, C. (2014). Introductory econometrics for finance (3rd ed.). Cambridge University Press.

Bryman, A., \& Bell, E. (2015). Business research methods (4th ed.). Oxford, UK: Oxford University Press.

Burns, A. J., Roberts, T. L., Posey, C., Bennett, R. J., \& Courtney, J. F. (2015, March). Assessing the role of security education, training, and awareness on insiders' security-related behavior: An expectancy theory approach. In System Sciences (HICSS), 2015 48th Hawaii International Conference on System Sciences, pp. 3930-3940. https://doi.org/10.1109/HICSS.2015.471 
Campbell, D. T., \& Stanley, J. C. (2015). Experimental and Quasi-Experimental Designs for Research. Ravenio Books.

Chang'ach, J. K. (2018). An Historical Trajectory of the Economic Transformation of the Southern Keiyo Community in Kenya. Global Journal of Social Sciences Studies, 4(2), 52-69.

Chaveerug, A. (2011). The role of accounting information system knowledge on audit effectiveness of CPAs in Thailand. International Journal of Business Strategy, 11(3), 78-89.

Chidoko, C., \& Mashavira, N. (2014). An analysis of corporate governance in the banking sector of Zimbabwe. Humanities and Social Sciences Letters, 2(3), 174-180.

Cohen, A., \& Sayag, G. (2010). The Effectiveness of Internal Auditing: An Empirical Examination of its Determinants in Israeli Organisations, p. 9724. https://doi.org/10.1111/j.1835-2561.2010.00092.x

Cohen, J., Cohen, P., West, S. G., \& Aiken, L. S. (2013). Applied Multiple Regression/Correlation Analysis for the Behavioral Sciences (3rd ed.). Mahwah, New Jersey: Lawrence Erlbaum Associates.

Crawshaw, J. R., Van Dick, R., \& Brodbeck, F. C. (2012). Opportunity, fair process and relationship value: Career development as a driver of proactive work behaviour. Human Resource Management Journal, 22(1), 4-20. https://doi.org/10.1111/j.1748-8583.2011.00169.x

Ekpung, E. G. (2014). Public infrastructure spending and economic growth in Nigeria: An Error Correction Mechanism (ECM) approach. Journal of Social Economics Research, 1(7), 129-140.

Eshiet, U. E. (2017). Implications of Accountants Unethical Behavior and Corporate Failures. International Journal of Business, Economics and Management, 4(4), 82-94.

Feizizadeh, A. (2012). Strengthening internal audit effectiveness. Indian Journal of Science and Technology, 5(5), 2777-2778.

Field, A. (2009). Discovering statistics using SPSS (4th ed.). Sage Publications.

Finance Committee on Corporate Governance. (2000). Malaysian Code on Corporate Governance 2000. https://doi.org/10.1057/palgrave.crr.1540254

Fried, Y., Grant, A. M., Levi, A. S., Hadani, M., \& Slowik, L. H. (2007). Job Design in Temporal Context: A Career Dynamics Perspective. Journal of Organizational Behavior, 28(7), 911-927. https://doi.org/10.1002/job

Furiady, O., \& Kurnia, R. (2015). The Effect of Work Experiences, Competency, Motivation, Accountability and Objectivity towards Audit Quality. Procedia - Social and Behavioral Sciences, 211, 328-335. https://doi.org/10.1016/j.sbspro.2015.11.042

Gong, Y., \& Chang, S. (2008). Institutional Antecedents and Performance Consequences of Employment Security and Career Advancement Practices: Evidence from The People's Republic of China. Human Resource Management, 47(1), 33-48. https://doi.org/10.1002/hrm

Güngör, P. (2011). The relationship between reward management system and employee performance with the mediating role of motivation: A quantitative study on global banks. Procedia - Social and Behavioral Sciences, 24, 1510-1520. https://doi.org/10.1016/j.sbspro.2011.09.029

Hackman, J. R., \& Porter, L. W. (1968). Expectancy Theory Predictions of Work Effectiveness 1. Organizational Behavior and Human Performance, 3, 417-426. Retrieved from http://ac.els-cdn.com/0030507368900184/1-s2.0-0030507368900184-main.pdf?_tid=9d1f661a-08c7-11e7-96d2 -00000aacb35d\&acdnat=1489504088_c1b5f43f51068708438219713b329bca

Hudiwinarsih, G. (2010). Auditor's Experience, Competency, and Their Independency As the Influencial Factors in Professionalism. Journal of Business and Accountancy Ventura, 13(3), 253-264.

Iskandar, T. M., Lasa, Y. M., \& Hassan, N. S. A. (2014). Financial management performance of public sector: quality of internal auditor. Int. J. Accounting, Auditing and Performance Evaluation, 10(3), 229-254.

Jones, G. R., \& George, J. M. (2015). Essentials of Contemporary Management (7th ed.). McGraw-Hill Higher Education.

Ketua Setiausaha Perbendaharaan. (2014). 1Pekeliling Perbendaharaan (1PP).

Khan, H., Hassan, R., \& Marimuthu, M. (2017). Diversity on Corporate Boards and Firm Performance: An Empirical Evidence from Malaysia. American Journal of Social Sciences and Humanities, 2(1), 1-8. 
Kimengsi, J. N., \& Gwan, S. A. (2017). Reflections on Decentralization, Community Empowerment and Sustainable Development in Cameroon. International Journal of Emerging Trends in Social Sciences, 1(2), 53-60.

Kolibácová, G. (2014). The relationship between competency and performance. Acta Universitatis Agriculturae et Silviculturae Mendelianae Brunensis, 62(6), 1315-1327. https://doi.org/10.11118/actaun201462061315

Kong, H., Wang, S., \& Fu, X. (2015). Meeting career expectation: can it enhance job satisfaction of Generation Y?. International Journal of Contemporary Hospitality Management, 27(1), 147-168. https://doi.org/10.1108/IJCHM-08-2013-0353

Kraimer, M. L., Seibert, S. E., Wayne, S. J., Liden, R. C., \& Bravo, J. (2011). Antecedents and Outcomes of Organizational Support for Development: The Critical Role of Career Opportunities. Journal of Applied Psychology, 96(3), 485-500. https://doi.org/10.1037/a0021452

Mahzan, N., \& Lymer, A. (2014). Examining the adoption of computer-assisted audit tools and techniques. Managerial Auditing Journal, 29(4), 327-349. https://doi.org/10.1108/MAJ-05-2013-0877

Mejdoub, H., \& Arab, M. B. (2017). A Multivariate Analysis for Risk Capital Estimation in Insurance Industry: Vine Copulas. Asian Development Policy Review, 5(2), 100-119.

Mihret, D. G., \& Yismaw, A. W. (2007). Internal audit effectiveness: an Ethiopian public sector case study. Managerial Auditing Journal, 22(5), 470-484. Retrieved from http://www.emeraldinsight.com/doi/abs/10.1108/02686900710750757

Minister for Human Services. (2017, February 28). Government Welcomes ANAO Report. Australian Government.

Mizrahi, S., \& Ness-Weisman, I. (2007). Evaluating the Effectiveness of Auditing in Local Municipalities using Analytic Hierarchy Process (AHP): A General Model and the Israeli Example. International Journal of Auditing, 11(3), 187-210. https://doi.org/10.1111/j.1099-1123.2007.00364.x

Mustapha, M., \& Lai, S. J. (2017). Information Technology in Audit Processes: An Empirical Evidence from Malaysian Audit Firms. International Review of Management and Marketing, 7(2), 53-59.

National Audit Department Malaysia. (2016). Auditor general's report 2015: Government's Financial Statement, Financial Management for the year 2015 and Activities of the Federal Ministries. Departments and Management of the Government's Companies Series 1.

National Audit Department. (2007). Penilaian Audit Terhadap Keberkesanan Peranan Unit Audit Dalam Pihak Berkuasa Tempatan di Seluruh Negara.

National Audit Department. (2017). Auditor General's Report 2016.

National Audit Department. (n.d.). National Audit Department. Retrieved December 1, 2017, from https://www.audit.gov.my/

National Audit Office. (n.d.). National Audit Office. Retrieved December 1, 2017, from https://www.nao.org.uk/

Oitsile, B., Galebotswe, O., \& Sekwati, L. (2018). Insurance-Economic Growth Nexus: Evidence from Botswana. Asian Economic and Financial Review, 8(6), 843-852.

Okon, E. O., \& Monday, O. I. (2017). Empirical and Evidence-Based Investigation: External Debt, Poverty and Economic Growth Nexus. International Journal of Applied Economics, Finance and Accounting, 1(1), 37-47.

Omodero, C. O., \& Ogbonnaya, A. K. (2018). Corporate Tax and Profitability of Deposit Money Banks in Nigeria. Journal of Accounting, Business and Finance Research, 3(2), 47-55.

Ormrod, J. E., \& Leedy, P. D. (2005). Practical research: Planning and design. New Jersey: Pearson Merill Prentice Hall.

Othman, R., Aris, N. A., Mardziyah, A., Zainan, N., \& Amin, N. M. (2015, April). Fraud Detection and Prevention Methods in the Malaysian Public Sector: Accountants' and Internal Auditors' Perceptions. Procedia Economics and Finance, 28, 59-67. https://doi.org/10.1016/S2212-5671(15)01082-5

Pallant, J. (2013). SPSS survival manual (5th ed.). McGraw-Hill Education (UK).

Perbendaharaan Malaysia. (2014). PS3.1 Pelaksanaan Audit Dalam Di Kementerian Atau Jabatan Persekutuan Dan Kerajaan Negeri.

Perbendaharaan Malaysia. (2014). PS3.2 Penubuhan Jawatankuasa Audit Di Peringkat Kementerian Persekutuan Dan Kerajaan Negeri. 
Rasit, M. H. H., Saidin, S. Z., Sahdan, M. H., Rahim, M. S., Gloeck, J. D., \& Ali, A. M. (2013). Internal Audit in the Federal Government Organizations of Malaysia: The Good, The Bad and The Very Ugly?. Asian Journal of Business and Governance, 2(1), 68-110.

Razek, M. A. (2014). The Association Between Corporate Risk Disclosure and Firm Performance in Emerging Country-The Case of Egypt. Journal of Empirical Studies, 1(3), 105-115.

Romli, A. A. N., \& Ismail, S. (2014). Quality Management Practices towards Customer Satisfaction in Local Authority Public Services Website. International Journal of Public Policy and Administration Research, 1(3), $80-93$.

Rosli, K., Siew, E.-G., \& Yeow, P. H. P. (2016). Technological, Organisational and Environmental Aspects of Audit Technology Acceptance. International Journal of Business and Management, 11(5), 140-145. https://doi.org/10.5539/ijbm.v11n5p140

Salvioni, D. M., \& Gennari, F. (2014). Corporate Governance, Sustainability and Capital Markets Orientation. International Journal of Management and Sustainability, 3(8), 469-483.

Sarwar, N., \& Mubarik, M. S. (2014). Foreign Direct Investment (FDI) and Employment: A Case of Province of Punjab, Pakistan. The Economics and Finance Letters, 1(4), 59-65.

Securities Commission Malaysia. (2012). Malaysian Code on Corporate Governance 2012. https://doi.org/10.1007/s13398-014-0173-7.2

Securities Commission Malaysia. (2017). Malaysian Code on Corporate Governance 2017.

Securities Commission. (2007). Malaysian Code on Corporate Governance 2007. https://doi.org/10.1007/s13398-014-0173-7.2

Shamsuddin, A., Manjiegar, D. B., \& Kirupanangtan, K. (2014). Factors that determine the effectiveness of internal audit functions in the malaysian public sectors. International Journal of Business, Economics and Law, 5(1), 9-17.

Soh, D. S. B., \& Martinov-Bennie, N. (2011). The internal audit function. Perceptions of internal audit roles, effectiveness and evaluation. Managerial Auditing Journal, 26(7), 605-622. https://doi.org/10.1108/02686901111151332

Su, J.-M., Lee, S.-C., Tsai, S.-B., \& Lu, T.-L. (2016). A comprehensive survey of the relationship between self-efficacy and performance for the governmental auditors. SpringerPlus, 5(1), 508. https://doi.org/10.1186/s40064-016-2104-x

Sulistyowati, L., \& Supriyati. (2015). The Effect of Experience, Competence, Independence and Professionalism of Auditors on Fraud Detection. The Indonesian Accounting Review, 5(1), 95-110. https://doi.org/10.14414/tiar.15.050110

Sun, C. (2012). From CAATTs Adoption to Continuous Auditing Systems Implementation: An Analysis Based on Organizational Routines Theories. MIS Review, 17(2), 59-85.

Systems (PACIS). 195.

The Australian National Audit Office. (n.d.). The Australian National Audit Office. Retrieved December 1, 2017, from https://www.anao.gov.au

The Edge Malaysia Weekly. (2016). Tabung Haji's oil and gas woes. The Edge Malaysia Weekly. Retrieved from $\mathrm{http}: / / w w w . t h e e d g e m a r k e t s . c o m / a r t i c l e / t a b u n g ? h a j i ' s-o i l-a n d-g a s-w o e s$

The Edge Markets. (2017). Felda registers RM1.2b in losses from stake in FGV. The Edge Markets. Retrieved from $\mathrm{http} / / / \mathrm{www}$.theedgemarkets.com/article/felda-registers-rm12b-losses-stake-fgv

The Institute of Internal Auditors Malaysia. (n.d.). Profile. Retrieved September 2, 2017, from http://www.iiam.com.my/profile/

The Institute of Internal Auditors. (2010, December). Measuring Internal Audit Effectiveness and Efficiency, pp. $1-16$.

The Institute of Internal Auditors. (2017). Public Sector Internal Audit (PSIA) Conference 2017. Retrieved from https://www.iia.org.sg

The Institute of Internal Auditors. (n.d.-a). About Internal Auditing. Retrieved September 2, 2017, from 
https://global.theiia.org/about/about-internal-auditing/Pages/About-Internal-Auditing.aspx

The Institute of Internal Auditors. (n.d.-b). About The IIA. Retrieved September 2, 2017, from https://global.theiia.org/about/about-the-iia/Pages/About-The-Institute-of-Internal-Auditors.aspx

The Institute of Internal Auditors. (n.d.-c). The Institute of Internal Auditors. Retrieved September 2, 2017, from https://global.theiia.org/standards-guidance/mandatory-guidance/Pages/Definition-of-Internal-Auditing.aspx

The Star Online. (2016). Ambrin: RM2bil recovered from audits. The Star Online.

The Star Online. (2017). EPF records RM203. 18mil realised loss from Felda Global Ventures stake. The Star Online. Retrieved

from http://www.thestar.com.my/news/nation/2017/04/03/epf-records-rm203mil-realised-loss-from-felda-global-vent ures-stake/

The Star. (2017). Former AG Ambrin wants greater autonomy for his old department. Retrieved from http://www.thestar.com.my/news/nation/2017/04/13/former-ag-ambrin-wants-greater-autonomy-for-his-old-dep $\mathrm{t} /$

The Sun Daily. (2016, November 23). Punitive warnings for civil servants doubled in AG â€TM s Report 2015, says Ali Hamsa. The Sun Daily.

The Sun Daily. (2017a). Malaysia Airlines "slightly ahead of schedule " in recovery. Retrieved from http://www.thesundaily.my/print/421497

The Sun Daily. (2017b, July 17). 2016 Auditor-General's Report Still Contains Element of Corruption.

The Sun Daily. (2017c, July 31). AG: Ministries, Govt Agencies, Depts Fail to Comply with Financial Regulations.

The Sun Daily. (2017d, August 3). Govt to investigate 103 punitive warnings from 2016 A-G Report.

Tippins, M. J., \& Sohi, R. S. (2003). IT competency and firm performance: Is organizational learning a missing link?. Strategic Management Journal, 24(8), 745-761. https://doi.org/10.1002/smj.337

Uprichard, E. (2013). Sampling: bridging probability and non-probability designs. International Journal of Social Research Methodology, 16(1), 1-11. https://doi.org/10.1080/13645579.2011.633391

Ussahawanitchakit, P., \& Intakhan, P. (2011). Audit professionalism, audit independence and audit effectiveness of CPAs in Thailand. International Journal of Business Research, 11(2), 1-8.

Vathanophas, V., \& Thai-ngam, J. (2007). Competency Requirements for Effective Job Performance in The Thai Public Sector. Contemporary Management Research, 3(1), 45-70.

Venkatesh, V., \& Brown, S. A. (2013). Bridging the Qualitative-Quantitative Divide: Research in Information Systems. Management Information Systems Quaterly, 37(1), 21-54. Retrieved from http://site.iugaza.edu.ps/kdahleez/files/2014/02/44-BRIDGING-THE-QUALITATIVE-QUANTITATIVE-DIVI DE-GUIDELINES-FOR-CONDUCTING-MIXED-METHODS-RESEARCH-IN-INFORMATION-SYSTEMS -2013.pdf

Weaver, B., \& Wuensch, K. L. (2013). SPSS and SAS programs for comparing Pearson correlations and OLS regression coefficients. Behavior Research Methods, 45(3), 880-895. https://doi.org/10.3758/s13428-012-0289-7

Wells, R. S., Kolek, E. A., Williams, E. A., \& Saunders, D. B. (2015). How we know what we know: A systematic comparison of research methods employed in higher education journals, 1996-2000 v. 2006-2010. Journal of Higher Education, 86(2), 171-195. https://doi.org/10.1353/jhe.2015.0006

Wilson Von Voorhis, C. R., \& Morgan, B. L. (2007). Understanding power and rules of thumb for determining sample sizes. Tutorial in Quantitative Methods for Psychology, 3(2), 43-50. Retrieved from http://www.tqmp.org/Content/vol03-2/p043/p043.pdf

Yusof, N. A. Z. M., Haron, H., \& Ismail, I. (2016). Internal Audit Practice in Malaysian Public Sector Organizations. The National Conference for Postgraduate Research, pp. 120-126.

Zaim, H., Yaşar, M. F., \& Ünal, Ö. F. (2013). Analyzing the Effects of Individual Competencies on Performance: a Field Study in Services Industries in Turkey. Journal of Global Strategic Management, 7(2), 67-77. https://doi.org/10.20460/JGSM.2013715668 